Notre Dame Law School

NDLScholarship

Journal Articles

Publications

9-2014

\title{
Just, Smart: Civil Rights Protections and Market- Sensitive Vacant Property Strategies
}

James J. Kelly Jr.

Notre Dame Law School, j.kelly@nd.edu

Follow this and additional works at: https://scholarship.law.nd.edu/law_faculty_scholarship

Part of the Civil Rights and Discrimination Commons, and the Housing Law Commons

\section{Recommended Citation}

James J. Kelly Jr., Just, Smart: Civil Rights Protections and Market-Sensitive Vacant Property Strategies, 23 J. Affordable Hous. \& Cmty. Dev. L. 209 (2014-2015).

Available at: https://scholarship.law.nd.edu/law_faculty_scholarship/1132

This Article is brought to you for free and open access by the Publications at NDLScholarship. It has been accepted for inclusion in Journal Articles by an authorized administrator of NDLScholarship. For more information, please contact lawdr@nd.edu. 


\title{
Just, Smart: Civil Rights Protections and Market-Sensitive Vacant Property Strategies
}

\author{
James J. Kelly, Jr.
}

\section{Contents}

I. Civil Rights Protections Related to Community Development ....... 212

A. Fourteenth Amendment ................................................................. 212

B. Fair Housing Act ................................................................... 213

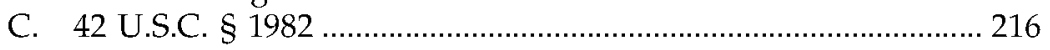

D. Antidiscrimination Requirements of Federal Funding

Programs ................................................................................ 218

E. Summary .............................................................................. 219

II. Civil Rights Concerns About Market-Sensitive Vacant Property

Strategies ............................................................................................ 220

A. Disparate Treatment Based on Race ........................................ 221

B. State and Local Agencies as Real Estate Market Participants.. 221

C. The Impact of Market-Sensitive Code Enforcement and LandBanking Strategies on Occupied Properties and Affordable Housing

D. Communicating the Fair Housing Benefits of Market-Sensitive

Vacant House Strategies.

Many American cities confronting an epidemic of vacant and abandoned properties made worse still by the continuing nation-wide foreclosure crisis are exploring innovative strategies for preventing, abating, and transforming vacant property nuisances. Most if not all of these vacant property strategies select tactics based on the strength of neighborhood real estate markets. The code enforcement decision to compel an owner to repair a vacant house, as opposed to requiring that the property be kept clean and boarded or that it be demolished, could hinge not only on the condition of the property but also on the values of the occupied houses around it. ${ }^{1}$ If the cost of the repairs will exceed the resale value of the rehabilitated property, then very frequently it will be difficult, if not

1. See James J. Kelly Jr., A Continuum In Remedies: Reconnecting Vacant Houses to the Market, 33 St. Louis Pub. L. Rev. 109, 111-17 (2013).

James J. Kelly, Jr. is Clinical Professor of Law, Notre Dame Law School. I would like to thank Jennifer Mason McAward, Sara Toering, Alan Mallach, and Morgan Williams for their comments on earlier drafts of this article. 
impossible, to bring about renovation through code enforcement coercion. $^{2}$ In healthier neighborhoods, on the other hand, code enforcement on vacant houses directed toward full compliance not only can be achieved more readily but also can have crucial positive impact throughout the neighborhood. ${ }^{3}$ The direct response options remaining for vacant houses in more distressed neighborhoods include minimization of safety threats, strategic acquisition for coordinated redevelopment, and demolition. For these neighborhoods, land banking may be more important than code enforcement in responding to large numbers of vacant properties. ${ }^{4}$

Using neighborhood real estate market data, public officials may respond to two nearly identical vacant houses in similar physical condition very differently. With the repeated application of a market-sensitive approach, neighborhoods that have just enough market strength to support rehabilitation with little or no public subsidy may receive code enforcement remedies that promptly, albeit incrementally, improve their stability. Poorer neighborhoods, on the other hand, may be relegated to long-term strategies that focus on reuse of vacant lots and large-scale redevelopment. Furthermore, citizen perception that an undercrowded neighborhood is being treated as a potential blank canvas for upscale development can be aggravated by land-bank disposition procedures that try to overcome weak neighborhood markets by requiring that vacant properties be sold in bundles. Thus, both code enforcement and land-banking procedures that treat similar houses differently because of their location in different types of neighborhoods can be controversial, especially given the undeniable reality that more distressed neighborhoods have substantially higher percentages of residents of color.

Any public allocation of resources in favor of neighborhoods perceived to be more stable begs for comparison to the "redlining" procedures used by federal mortgage insurers before, during, and immediately after World

2. Id. at 117. In many distressed neighborhoods, the presence of other vacant and abandoned houses depresses the resale price of a renovated property below the cost of the rehabilitation, making full compliance with code financially unworkable.

3. Through its Vacants to Value program, Baltimore's Housing and Community Development Department has developed a streamlined approach to code enforcement specifically targeted at healthier neighborhoods. Explore City Neighborhoods, VACANTS TO VALUE, http://www.vacantstovalue.org/Explore.aspx\#codeenf.

4. Neighborhoods that lack the market strength to support individual renovations may benefit from a land bank coordinating the renovation of all the vacant properties on a block or group of blocks. Kelly, supra note 1, at 112. More intractable problems such as inadequate lot sizes and obsolete housing stock may require more comprehensive land assembly, to which land banking can contribute even if eminent domain may ultimately be invoked. Frank S. AleXaNDER, LAND BaNKS AND Land Banking 61 (2011). See also, Alan Mallach, Bringing Buildings Back: From Abandoned Properties to Community Assets 105-11 (2d ed. 2010). 
War II. Rather than challenge the racially discriminatory lending practices of that era, the Federal Housing Administration used maps that discouraged lending in areas that were attracting African American residents and adopted underwriting policies that encouraged the use of racially restrictive deed covenants to preserve racial homogeneity. ${ }^{5}$ Several scholars have pointed to this subsidized fostering of affluent and overwhelmingly white suburbs as a key component in the gathering of the inner-city underclass into distressed ghetto neighborhoods. ${ }^{6}$ Public officials using neighborhood strength as a guiding principle in code enforcement and land-banking approaches to vacant houses must be able to communicate the rationale behind these approaches and be prepared to do so in actual courts as well as in the court of public opinion.

Given the contentious nature of inner-city neighborhood development decisions and the stark history of discriminatory practices and outcomes in housing policy, it is crucial for those responsible for dealing with vacant property crises in their communities to be just as well as smart in planning and deploying market-sensitive vacant property strategies. Because civil rights law as applied to government actors addresses deliberate discrimination, unintended harm to minorities, and government's affirmative obligations to pursue racial justice, a thorough understanding of the relevant law is essential to forming a just and smart vacant property strategy.

Part I of this paper will explore four primary areas of civil rights protection: the Fourteenth Amendment's guarantee of equal protection under state and local laws, the Fair Housing Act's ban on discrimination in the area of access to housing, Reconstruction-era prohibitions on discrimination with regard to property rights, and requirements that state and local government recipients of federal funding eliminate discrimination and promote equality. Part II will review the civil rights vulnerabilities of code enforcement and land-banking strategies that manage properties

5. Douglas S. Massey \& Nancy A. Denton, American Apartheid: Segregation AND tHe MAKing of the UndercLass 53-54 (1993).

6. In Planned Abandonment: The Neighborhood Life-Cycle Theory and National Urban Policy, 11 Housing Policy Debate 7 (2000), John Metzger attacked Anthony Downs' "[t]riage planning as the synthesis of the redlining thesis and the postriot FHA [greenlining to promote neighborhood stability] antithesis." Id. at 24. Metzger defined triage planning as the "target[ing of] federal funds to neighborhoods where there was a moderate decline in property values but not yet a clear downward trend of population loss, housing abandonment, and increasing poverty." Id. at 17 . For a response by Downs and others, see Anthony Downs, Commentary, John T. Metzger's "Planned Abandonment: The Neighborhood Life-Cycle Theory and National Urban Policy," 11 Housng Policy Debate 41 (2000); George C. Galster, Commentary, John T. Metzger's "Planned Abandonment: The Neighborhood Life-Cycle Theory and National Urban Policy," 11 Housing Policy Debate 61 (2000); and Kenneth Temkin, Commentary, John T. Metzger's "Planned Abandonment: The Neighborhood Life-Cycle Theory and National Urban Policy," 11 Housing Policy Debate 55 (2000). 
differently based on the neighborhood market context in which they are located. Based on the conclusions reached in the first part, the recommendations of the second part will be shaped strongly by two aspects of Fair Housing Act enforcement: first, the relevance of disparate impact evidence to a legal claim that a local government is making dwellings unavailable to persons of color and, second, the obligations of local Department of Housing and Urban Development (HUD) fund recipients to affirmatively further fair housing in their communities.

\section{Civil Rights Protections Related to Community Development}

During most of the nation's first century, the federal government had little power to affect state laws regarding race and slavery. The ratification of the Thirteenth, Fourteenth, and Fifteenth amendments during the first five years of Reconstruction completely transformed the federal government's constitutional authority to eliminate racial discrimination. The Fourteenth Amendment guaranteed all persons in the United States equal protection under state law. Two and a half years earlier, the ratification of the Thirteenth Amendment abolished slavery. In the meantime, Congress, using the authority given to it by the Thirteenth Amendment to eliminate "badges of slavery," enacted the Civil Rights Act of 1866, which guaranteed to "all citizens ... the same right . . . enjoyed by white citizens . . .to inherit, purchase, lease, sell, hold, and convey real and personal property." 7 The Fourteenth Amendment's general ban on state-sponsored discrimination and the 1866 prohibition on private and public racial discrimination with regard to private property gave some security to African Americans' rights to housing. Title VIII of the Civil Rights Act of 1968, known as the Fair Housing Act, however, explicitly and comprehensively secured the rights of African Americans to live where they saw fit without interference or intimidation. To understand the civil rights environment in which local government neighborhood development strategies operate, each of these three sets of individual protections must be examined, together with federal antidiscrimination restrictions on the use of resources provided by federal housing and community development programs.

\section{A. Fourteenth Amendment}

The Fourteenth Amendment to the U.S. Constitution provides that "[n]o State shall ... deny to any person within its jurisdiction the equal protection of the laws." The Amendment prohibits, absent compelling justification, disparate treatment under the law based on race or ethnicity. Although its reach has been limited to state action, it bans discrimination not only through criminal and civil laws but also in every manner of governmental conduct. No government-sponsored project can be undertaken or public resource used or distributed in a way that deliberately favors

7. U.S. CONST. amend. XIII. 
one racial group over another, unless such favoritism is needed to further a compelling governmental interest. ${ }^{8}$ Nor is the scope of a court's inquiry limited to the text of the law or policy. A race-neutral, facially valid state or local law may be administered in a race-conscious manner that justifies relief under the Fourteenth Amendment. ${ }^{9}$ Since explicitly race-conscious procedures, outside affirmative action, are rare enough in state and local government systems, the crucial issue within equal protection law has been whether procedures that have the effect, but not the intent, of favoring one racial group over another are unconstitutional.

In Washington v. Davis, the U.S. Supreme Court rejected disparate impact as a stand-alone basis for declaring a state or local law invalid under equal protection. ${ }^{10}$ The fact that a law has the effect of disadvantaging a protected racial group can, however, be used as evidence of an otherwise hidden discriminatory agenda. Sometimes, the standard animating a law or policy appears to be nondiscriminatory but has such a strong negative impact on a racial minority as to raise questions about the motives of the policymakers. In those cases where a facially race-neutral classification is used as a proxy for a racial categorization, the courts have looked at the strong correlation between the racial and "non-racial" groupings as one part of a circumstantial case for intentional discrimination. ${ }^{11}$ For instance, in overwhelmingly white cities or towns where public housing residency is overwhelmingly nonwhite, onerous restrictions on the siting of new public housing projects have been found to be racially motivated. ${ }^{12}$ But the standard for invalidating a state or local law or procedure under the Fourteenth Amendment's Equal Protection Clause remains proof of deliberate discrimination rather than proof of discriminatory effect alone.

\section{B. Fair Housing Act}

While a showing of intentional racial discrimination is required to establish unconstitutionality, the standards for protection under more targeted civil rights statutes have not been found to be so demanding. Prior to the Supreme Court's issuing its decision in Washington v. Davis, federal courts decided in favor of a "disparate impact" approach to the standard for relief under civil rights statutes enacted in the 1960s. In United States v. City of Black Jack, the U.S. Court of Appeals for the Eighth Circuit held that to obtain relief under Title VIII of the Civil Rights Act of 1968, also known as the Fair Housing Act, plaintiffs "need prove no more than that the conduct of the defendant actually or predictably results in discrimination; in other

\footnotetext{
8. Loving v. Virginia, 388 U.S. 1 (1967).

9. Yick Wo v. Hopkins, 118 U.S. 356 (1886).

10. 426 U.S. 229 (1976).

11. See Gomillion v. Lightfoot, 364 U.S. 339 (1960) (racial gerrymandering).

12. See, e.g., United States v. Yonkers Bd. of Educ., 635 F. Supp. 1577 (S.D.N.Y.
} 1986). 
words, that it has a discriminatory effect."13 Previously, in Griggs v. Duke Power Co., a unanimous U.S. Supreme Court had held that the employment nondiscrimination provisions of the Civil Rights Act of 1964 had been intended to achieve equality in the workplace and that a showing of actual racial bias was not a prerequisite to invalidating a practice that had demonstrated discriminatory effect, at least not in the absence of a nonracial justification. ${ }^{14}$ The Supreme Court reached this conclusion despite language in the statute that prohibited adverse actions taken "because of such individual's race." ${ }^{15}$ Although the Court has not yet ruled on the merits of a Fair Housing Act case, there seems to be a consensus among lower courts that proof of intent is not indispensable to a claim for relief.

The Fair Housing Act makes it illegal to engage in any one of a list of discriminatory residential real estate activities, including racially motivated rejection or steering of a prospective tenant or homebuyer, discriminatory advertising, and blockbusting. ${ }^{16}$ It also prohibits interference with the efforts of third parties to assist persons exercising their rights to fair housing. ${ }^{17}$ While most of these prohibitions affect the operations of state and local governments only to the extent that they engage directly in the marketing or financing of residential real estate, one key section of the Fair Housing Act has profoundly shaped a broad array of land use and community development policies.

The same provision of the Fair Housing Act that bans the rejection of a prospective tenant or homebuyer on account of race also makes it illegal "to make unavailable or deny a dwelling to any person because of race. ..." Coalitions of civil rights groups, affordable housing activists, and antipoverty advocates have used this language in the Fair Housing Act to challenge an array of housing assistance, ${ }^{18}$ community development, ${ }^{19}$ and zoning ${ }^{20}$ policies and decisions made at the local level. In deciding whether to invalidate local policies under the Fair Housing Act, courts have relied on statistical evidence of disproportionate adverse im-

13. 508 F.2d 1179, 1184 (1974).

14. 401 U.S. 424 (1971) (general intelligence test not found to be predictive of effective employees but adversely impacted hiring of African American workers).

15. Id. The Fair Housing Act also contains the phrase "because of race. . . ." 42 U.S.C $\$ 3604$. In 1991, the employment discrimination statute was amended to codify the disparate impact test. Even so, at least one Supreme Court justice maintains that the disparate impact test may itself be invalid under the Equal Protection provisions of the U.S. Constitution. Ricci v. DeStefano, 557 U.S. 557, 594-96 (2009) (Scalia, J., concurring).

16. 42 U.S.C. $\$ \S 3604,3605$.

17. 42 U.S.C. $\S 3617$.

18. See, e.g., Gautreaux v. Chi. Hous. Auth., 436 F.2d 306 (7th Cir. 1970).

19. See, e.g., Resident Advisory Bd. v. Rizzo, 564 F.2d 1261 (3d Cir. 1977).

20. See, e.g., Metro. Hous. Dev. Corp. v. Arlington Heights, 558 F.2d 1283 (1977), cert. denied, 434 U.S. 1025 (1978). 
pact on a minority population's access to housing in the jurisdiction and the tendency to perpetuate already-existing patterns of housing segregation. ${ }^{21}$ They have also, however, allowed defendant jurisdictions to present evidence of race-neutral public policy objectives, especially when those goals cannot be achieved without the cited adverse impacts. ${ }^{22}$

The Seventh Circuit's four-factor test, sometimes labeled "impact plus," incorporated elements of both effect and intention and has had broad influence. ${ }^{23}$ In reviewing the denial of a petition to rezone a parcel of land to allow for the construction of a subsidized, affordable apartment complex in Metropolitan Housing Development Corp. v. Arlington Heights, the Seventh Circuit Court of Appeals found that the plaintiffs' evidence should be judged by weighing the following factors: the presentation of strong evidence for discriminatory effect; the existence of some evidence for discriminatory intent; the lack of a substantial nondiscriminatory basis for the defendant's action; and a showing that the defendant is interfering with, rather than merely failing to produce, housing opportunities for protected persons of color. ${ }^{24}$

Both equal protection and fair housing jurisprudences recognize the significance of both the outcomes for protected persons and the motives of policymakers in evaluating the discriminatory nature of a governmental law or action. Under the Fourteenth Amendment, disparate impact evidence will help invalidate a state action only to the extent it helps establish deliberate discrimination. With the Fair Housing Act, plaintiffs can establish an entitlement to relief with a strong showing of discriminatory effect but must be prepared to refute counterarguments from defendants that the challenged policies are both motivated and justified by legitimate public welfare concerns untainted by racial bias. The Eighth Circuit has articulated a burden-shifting sequence that requires a defendant, only after the plaintiff has established adverse impact on a minority group, to show the challenged policy is manifestly related to a legitimate, nondiscriminatory public objective. ${ }^{25}$ Then, the plaintiff would be able to argue that the objective could be achieved by an alternative policy without the discriminatory effects. ${ }^{26}$ As of February 2013, HUD has adopted this burden-shifting approach to disparate impact claims in the fair housing complaints it handles administratively. ${ }^{27}$ As the experience of the code

21. John E. Theuman, Annotation, Evidence of Discriminatory Effect Alone as Sufficient to Prove, or to Establish Prima Facie Case of, Violation of Fair Housing Act, 100 A. L.R. FED. 97, § 2(a) (1990).

22. Bradley v. HUD, 658 F.2d 290 (5th Cir. 1981).

23. Metro. Hous. Dev. Corp., 558 F.2d 1283.

24. Id.

25. Gallagher v. Magner, 619 F.3d 823 (8th Cir. 2010); Darst-Webbe Tenant Ass'n Bd. v. St. Louis Hous. Auth., 417 F.3d 898 (8th Cir. 2005).

26. Darst-Webbe, 417 F.3d at 902-03.

27. 24 C.F.R. $\S 100.500$. 
enforcement division of St. Paul, Minnesota, before the Eighth Circuit Court of Appeals in the case of Gallagher v. Magner ${ }^{28}$ illustrates, this third step can make it difficult for defendants to avoid trial on policy choices that have adverse impacts on minority communities.

\section{42 U.S.C. $\$ 1982$}

The third primary source of federal civil rights protection against real estate discrimination actually predates the enactment of the Fourteenth Amendment. The Civil Rights Act of 1866 required states to provide all citizens "the same right . . . as is enjoyed by white citizens . . to . . . purchase (and) lease . . real and personal property. "29 Unlike the Fair Housing Act, which it preceded by more than a century, its guarantees are not limited to transactions involving residential occupancy but extend to all manner of property rights. Any doubts as to whether it, like the Fourteenth Amendment, was limited to discrimination by state actors were eliminated by the 1968 Supreme Court decision in Jones $v$. Alfred $H$. Mayer Co., which held that the provision prohibited both public and private discrimination concerning rights in property because the statute should be interpreted broadly as a remedial measure. ${ }^{30}$ The Court concluded that Congress clearly expressed its intent and did not exceed the authority it had received from the recent enactment of the Thirteenth Amendment, which not only eliminated slavery throughout the United States but empowered Congress to eliminate "badges of slavery." 31 Section 1982 has been held not only to protect citizens against discriminatory destruction of property rights but also discriminatory exclusion from particular benefits associated with property ownership, such as limitedaccess amenities. ${ }^{32}$

Despite its apparent overlap with the Fourteenth Amendment and the Fair Housing Act, the standard of proof for and the scope of relief under the provision, codified as $\S 1982$, were the focus of litigation when the City of Memphis closed a through street that connected a black neighborhood to the largely white community adjacent to it. ${ }^{33}$ Without clear evidence of racial animus by the municipal government or strong evidence that anyone would be denied housing opportunities as a result of the city's action, the plaintiffs in the case pressed their claims under $\S 1982$ and the Thirteenth Amendment. A divided Sixth Circuit held that the erection of a physical barrier disadvantaged and stigmatized the African American homeowners and thereby constituted the type of property-right-discrimination

28. 619 F.3d 823. For discussion, see infra notes $56-58$ and accompanying text.

29. 42 U.S.C. $\S 1982$.

30. 392 U.S. 409 (1968).

31. Id. at 439 (citing Civil Rights Cases, 109 U.S. 3, 20 (1883)).

32. Sullivan v. Little Hunting Park, Inc., 396 U.S. 279 (1969) (racially motivated denial of pool membership held invalid).

33. City of Memphis v. Greene, 610 F.2d 395 (6th Cir. 1980). 
"badge of slavery" that Congress prohibited through $\S 1982 .{ }^{34}$ On appeal, the U.S. Supreme Court reversed and found that the closing of the road was justified by traffic safety concerns and constituted little more than an inconvenience, albeit one disproportionately visited upon the residents of the largely African American subdivision. ${ }^{35}$ The majority opinion did not go so far as to say that $\S 1982$ applied only in those cases where deliberate discrimination could be proven. ${ }^{36}$ The Court found instead that the record did not support the lower court's factual conclusion that the street closure was an unusual and segregating public action that benefitted white residents to the disadvantage of African American residents and lowered the property values of the latter group. ${ }^{37}$

The question of whether $\ 1982$ requires a showing of disparate treatment, as opposed to mere disparate impact, remains open to some extent. Despite the fact that the text of $\S 1982$ could be read as guaranteeing equal legal outcomes to nonwhites situated similarly to whites, the federal courts have found discriminatory intent at least as relevant to $\S 1982$ relief as to a cause of action under the Fair Housing Act. ${ }^{38}$ Moreover, in General Building Contractors Ass'n v. Pennsylvania, the Supreme Court declared that 42 U.S.C. $§ 1981$, a similarly formulated Reconstruction-era federal civil rights statute protecting contract rights, called for as clear a showing of discriminatory intent as that required by the Fourteenth Amendment. ${ }^{39}$ But without a clear ruling on $\S 1982$ itself, state and local governments should not assume that disparate impact claims by homeowners and tenants can be brought only under the Fair Housing Act. They should be prepared to defend policy actions that adversely impact nonwhite property owners and nonwhite tenants, in both residential and commercial contexts, under an analysis as open to disparate impact claims as the impact-plus approach articulated in Metropolitan Housing Development Corp. v. Arlington Heights. ${ }^{40}$

34. "The closing of West Drive .. . would be, to blacks and whites alike, exactly what the trial judge said it was: an unmistakable warning to the black people living to the north of West Drive to stay out of the Hein Park subdivision." Id. at 404.

35. City of Memphis v. Greene, 451 U.S. 100 (1981).

36. A concurring opinion by Justice White did take the position that $\S 1982$ applied only to cases involving deliberate discrimination. Id.

37. Id. The Court distinguished the Memphis street closure from a street closing that was held invalid under $\S 1982$ by the Fifth Circuit because that government action denied all direct access of black residents to the neighboring white community and added two miles to their through travel in that direction.

38. Id.; Sullivan v. Little Hunting Park, Inc. 396 U.S. 279 (1969).

39. 102 S. Ct. 3141 (1982).

40. This was essentially the approach taken by the trial court in City of Memphis v. Greene that was not specifically rejected by the Sixth Circuit or the U.S. Supreme Court in their subsequent appellate reviews. 610 F.2d 395, 398 (6th Cir. 1980). 


\section{Antidiscrimination Requirements of Federal Funding Programs}

In addition to the general nondiscrimination obligations that they have under the Fourteenth Amendment, the Fair Housing Act, and $\S 1982$, state and local governments also assume, by receiving funds from the federal government, additional legal obligations to not discriminate and to affirmatively combat the negative historical effects of past discrimination. Title VI of the Civil Rights Act of 1964 provides that "[n]o person in the United States shall, on the ground of race, color or national origin, be excluded from participation in, be denied the benefits of, or be subjected to discrimination under any program or activity receiving Federal financial assistance." 41 As mentioned above, the Fair Housing Act makes it a core part of the mission of HUD to affirmatively further fair housing through its grants and programs. Both of these statutory provisions create obligations not to discriminate and thereby raise questions about the sufficiency of disparate impact evidence, as well as duties to pursue affirmative action in support of racial justice goals.

To claim successfully that a municipality has violated its obligations under Title VI, a plaintiff must first show that the plaintiff is an intended beneficiary of the program or funding in question. ${ }^{42}$ The sufficiency of disparate impact evidence as the basis for relief against a state or local federal funds recipient has had a long and tortured history in the federal courts. Suffice it to say, the Supreme Court has required private plaintiffs to show deliberate discrimination, but federal regulations that prohibit adverse impacts may still be enforced by federal agencies. ${ }^{43}$ The Court has held that the first section of Title VI prohibits only those actions that would violate the Equal Protection Clause because they involve deliberate discrimination. ${ }^{44}$ But a majority of justices have also agreed that the second section of Title VI empowers government agencies to adopt regulations that prohibit policies that disproportionately and adversely impact protected groups. ${ }^{45}$ In Alexander $v$. Sandoval, the Court applied these divergent approaches to enforcing nondiscrimination by federal funds recipients and declared that any private cause of action for nondiscrimination must establish a case for disparate treatment in order to receive relief under the statute. Nevertheless, state and local government officials should be mindful of the regulatory requirements specific to the federal programs they depend upon as well as the enforcement practices of the supervising federal agencies.

41. 42 U.S.C. $\$ 2000$ d.

42. Commodari v. Long Island Univ., 89 F. Supp. $2 d 353$ (E.D.N.Y. 2000), aff'd, 62 F. App'x 28 (2d Cir. 2003).

43. Alexander v. Sandoval, 532 U.S. 275 (2001).

44. Regents v. Bakke, 438 U.S. 265, 284 (1978).

45. Guardians Ass'n v. Civil Serv. Comm'n, 463 U.S. 582 (1983). 
Pursuant to Title VI, the Fair Housing Act, and the Housing and Community Development Act of 1974, HUD has issued regulations that prohibit a wide variety of discriminatory activities. ${ }^{46}$ HUD regulations also prohibit state and local partners from using "criteria or methods of administration that have the effect of subjecting persons to discrimination or have the effect of defeating or substantially impairing accomplishment of the objectives of the program or activity with respect to persons of a particular race, color, national origin, religion, or sex." 47 This regulation makes clear that state and local policies causing unintentional discrimination and adverse impacts that impair program objectives put future funding at serious risk. Disparate impact evidence appears to be sufficient to establish a violation of this regulation, especially when that impact compromises the benefits associated with the program in question.

In carrying out its Fair Housing Act mandate to "administer the programs and activities relating to housing and urban development in a manner affirmatively to further the policies of "the Fair Housing Act, ${ }^{48}$ HUD requires funding recipients to submit an Assessment of Fair Housing (AFH). This report analyzes the local jurisdiction's data and proposed strategies in four key areas: overcoming historic residential patterns of segregation; reducing racial and ethnic concentrations of poverty; reducing disparities in access to community assets; and responding to disproportionate needs for decent, affordable housing by members of protected groups. As part of an overall increase in attention to this part of its mission, HUD has issued a proposed final rule that will make key changes in the form, timing, and content of the AFH. ${ }^{49}$ The new AFH process will begin with HUD's provision of data related to four core fair housing goals. Each local jurisdiction will analyze the data and set goals and strategies, which it will then incorporate into its Consolidated Plan, required for its continued receipt of Community Development Block Grant (CDBG) funds.

\section{E. Summary}

The overall direction of this review of community-development-related civil rights protections has taken us from broad laws with demanding burdens of proof to focused regulations that prohibit even unintentional discrimination. The Fourteenth Amendment's Equal Protection Clause, a law of very broad scope, is limited to instances of deliberate discrimination by state actors. Title 42 U.S.C. $\$ 1982$ focuses on the property rights of minorities and may, like the Equal Protection Clause, be limited to cases of actual racial bias.

46. 24 C.F.R. $\S 6.4(\mathrm{a})(1)$.

47. 24 C.F.R. $\S 6.4(\mathrm{a})(1)(\mathrm{ix})$.

48. 42 U.S.C. $\$ 3608(\mathrm{e})(5)$.

49. A HUD guide to the new reporting process is available at http://www.huduser.org/portal/publications/pdf/affht_userFriendlyGuide.pdf. 
The Fair Housing Act guarantees equal access to housing and has been held by courts to prohibit policies that have clear discriminatory effect even when there has been little or no evidence of local policymakers' biased motivation. But while a policy that involves a constitutionally suspect racial classification can be saved only by a compelling governmental interest, a disparate impact claim under the Fair Housing Act can be turned aside by a local jurisdiction's showing that its policy choice was justified by a legitimate public policy objective, especially if that objective could not be achieved in a way that avoided adverse impacts on minorities. Finally, regulations governing the use of federal community development funds not only prohibit uses of those funds that have discriminatory impacts but also require reports from funded jurisdictions that state if and how those resources are being directed toward antidiscrimination goals generally. Significantly though, this last set of protections against unintended adverse impacts may be invoked only in administrative complaints brought by intended beneficiaries of federal funding or by HUD itself..$^{50}$

\section{Civil Rights Concerns About Market-Sensitive Vacant Property Strategies}

Looking then at the range of legal protections described above, local officials anticipating possible racial justice concerns should ensure not only that their vacant property programs neither deliberately discriminate against nor harm the housing opportunities of racial minorities but also that they integrate, rather than conflict, with other local efforts that promote a just as well as prosperous community. Doing so necessarily involves hearing and responding to the concerns of residents of distressed neighborhoods. Market-sensitive approaches to the vacant property crisis do not provide quick or easy answers to the severe problems that these community members have been living with for many years. Even if the law does not require furtherance of fair housing goals as strictly as it prohibits deliberate discrimination, local government's full engagement with its legal and moral obligations to promote racial justice provides a foundation for the inclusion of all local residents, especially those most affected by vacant property problems.

Ensuring a just and compliant approach to preventing and eliminating vacant property nuisances can be best accomplished by articulating best practices based on the four areas of law discussed in the previous part. Since all civil rights provisions categorically prohibit deliberate discrimination, the first recommendation to state and local governments could

50. While Sandoval did not eliminate the ability of intended beneficiaries of federal funding to assert the Title VI statutory protection in federal court, claims under the statute itself require proof of actual bias. See supra notes $43-45$ and accompanying text. 
not be more obvious: do not engage in intentional discrimination based on race. Second, all vacant property strategies that involve a local jurisdiction in the marketing, rental, or sale of real property require the same type or rigorous compliance review and training protocols that any professional residential real estate business would institute. Third, local officials should scrutinize market-sensitive approaches to code enforcement and vacant property acquisition and disposition for any adverse impacts on the housing opportunities and property values of citizens of color and explore with affected residents the possibilities for offsetting or eliminating them. ${ }^{51}$ Fourth, local jurisdictions need to communicate proactively about the fair housing benefits to be realized by market-sensitive vacant property strategies in their AFHs and discussions with neighborhood residents.

\section{A. Disparate Treatment Based on Race}

Deliberate discriminatory policies and practices can be better understood and eliminated when broken down into three types: explicitly biased, facially neutral but unlawfully race conscious, and substantively valid but administered in a biased manner. Any statute, regulation, or governmental policy that differentiates based on race and adversely impacts a racial minority is presumptively invalid. This direct and unquestioned application of the Fourteenth Amendment's Equal Protection Clause presents no problem for any strategies related to vacant properties as explicit racial classifications have no place in them. Even race-conscious systems that do not deliberately treat racial groups differently or that seek to address the lingering effects of past discrimination do not offer viable ways of dealing with vacant and abandoned properties. With regard to Fourteenth Amendment concerns, local jurisdictions implementing any code enforcement or land-banking strategy must work to make sure that the fair and nondiscriminatory procedures put in place are administered in an unbiased manner. Those who shape the policies will need to make legal judgments about how detailed written policies and procedures should be because giving inadequate guidance to personnel can lead to inconsistent actions. But professional public administration begins with careful hiring and high-quality training.

\section{B. State and Local Agencies as Real Estate Market Participants}

The link between professionalism and compliance with civil rights protections is all the more crucial when state and local governments take

51. This third section will also examine two recent examples of Fair Housing Act litigation concerning code-delinquent properties: the Eighth Circuit Court of Appeals decision in Gallagher v. Magner, 619 F.3d 823 (8th Cir. 2010), and a recent complaint filed by a coalition of advocates led by the National Fair Housing Alliance against a Fannie Mae subcontractor responsible for managing its real estate owned (REO) portfolio. 
direct part in the real estate business. Cities with multifamily dwellings neglected by their landlord have taken advantage of code enforcement provisions authorizing the appointment of a receiver to collect rents and make necessary repairs. Likewise, local land banks have sometimes opted to rent out properties in their inventory as an interim or longterm reuse strategy. Whenever local governments become landlords, they need to become as familiar with their obligations under the Fair Housing Act as any public housing authority or major private landlord is. Similarly, vacant house receivership and land bank dispositions involve these same actors in the marketing and sale of real estate. Code enforcement departments and land banks that rent out or sell properties they control to potential occupants must be vigilant about not only deliberate discrimination but also any "practice [that] . . actually or predictably results in a disparate impact on a" racial group. ${ }^{52}$ Thankfully, the protocols for fair housing compliance in core real estate activities, while far from easy, have been developed over a long period of time and are regular subjects of in-service trainings.

\section{The Impact of Market-Sensitive Code Enforcement and Land-Banking \\ Strategies on Occupied Properties and Affordable Housing}

To understand if and how market-sensitive vacant property strategies might be accused of having adverse impacts on communities of color in violation of federal statutes and regulations, we must examine how these strategies affect existing neighborhoods of color and how they impact affordable housing opportunities. Market-sensitive code enforcement strategies may aggressively eliminate vacant house nuisances in relatively stable neighborhoods while deferring such action in distressed neighborhoods. There may be sound racially neutral justifications for these policies on coercing rehabilitation that produce racially skewed results, but the same may not be true when it comes to policies regarding code enforcement efforts to minimize harms from vacant buildings still requiring renovation. Apart from the disparate impacts that policies might have on the minority residents of occupied properties, HUD has made it clear that policies that reinforce housing segregation or reduce minority opportunities for affordable housing also violate the Fair Housing Act. ${ }^{53}$ To ensure true success for vacant property strategies, city officials need to engage in dialogue with affected residents to hear their concerns about strategies and modify and complement market-sensitive vacant property strategies appropriately.

52. 24 C.F.R. $\S 100.500$ (a).

53. "A practice has a discriminatory effect where it actually or predictably results in a disparate impact on a group of persons or creates, increases, reinforces, or perpetuates segregated housing patterns because of race, color, religion, sex, handicap, familial status, or national origin." Id. 
Because vacant properties impact communities, the strategies chosen to combat vacant property problems also impact them. Derelict, vacant structures reduce the property values of the houses around them. ${ }^{54}$ The nuisances and dangers associated with vacant houses reduce the quality of life of neighboring residents. From the perspective of residents of distressed neighborhoods, market-sensitive vacant property strategies seek to coerce responsible owners of vacant properties in some neighborhoods to rehabilitate them while offering to delinquent owners in other neighborhoods amnesty from their failure to comply with the code. Even the publication of maps showing official judgments about neighborhood strength may be criticized as stigmatizing and counterproductive. Whether from these self-fulfilling prophecies of continuing decline or from the substantial harms caused by unabated nuisances, vacant property strategies may be criticized as contributing to, rather than alleviating, the housing problems of residents living in distressed neighborhoods.

To the extent that municipal services related to housing are being provided in a racially discriminatory manner, the Fair Housing Act is clearly implicated. But vacant property strategies that aggressively pursue immediate and complete nuisance abatement in neighborhoods that happen to have larger white populations do not necessarily violate the Fair Housing Act. A city's choices about how and when to pursue rehabilitation of a vacant structure result in adverse impacts for the city's African American residents, but as long as its choices to pursue orders to correct violations are based on nonracial, objective criteria strongly related to the likely success of its efforts, the strategic choices will not raise Fair Housing Act concerns. Public officials must have prosecutorial discretion to use their legal resources to maximize their effectiveness, even if they cannot show that pursuing orders to rehabilitate houses in severely distressed areas would not produce any actual rehabilitations. But this analysis may proceed differently when examining nuisance mitigation practices as opposed to the choices made with regard to pursuing total abatement of a nuisance.

The National Fair Housing Alliance, together with several other advocacy organizations, filed a HUD administrative complaint in July 2014 alleging that Cyprexx, Inc., a private, for-profit company hired by Fannie Mae to manage its REO portfolio, has violated the Fair Housing Act by not maintaining its properties in minority neighborhoods as diligently as those in largely white neighborhoods. ${ }^{55}$ Interestingly, the complaint does not claim that a greater percentage of the unoccupied properties

54. Stephen Whitaker \& Thomas J. Fitzpatrick IV, The Impact of Vacant, Tax-Delinguent, and Foreclosed Property on Sales Prices of Neighboring Homes 2 (2012).

55. The complaint filed against Cyprexx, together with information about lawsuits NFHA has previously filed against other REO managers, can be found at http:/ / www nationalfairhousing.org/REO/tabid/4265/Default.aspx. 
Cyprexx manages in white neighborhoods are compliant with the code, although that may be true. Instead, the complaint focuses on disparities in those violations that can be addressed through routine maintenance, even of a profoundly substandard structure. These include failure to cut the grass and cut back overgrown shrubs, failure to secure the property from casual entry, and failure to remove trash and debris. The complaint is not alleging that the Fair Housing Act demands that the Fannie Mae properties in distressed communities be just as code compliant as those in better-off areas, but it is insisting on the same level of routine maintenance that prevents an eyesore from becoming a neighborhood nightmare.

City officials dealing with vacant properties pursue interim nuisance mitigation strategies as well as permanent nuisance abatement plans. They push not only for rehabilitation or demolition but also for cleanup, mowing, and boarding up when required. Many times, cities are compelled to perform these services themselves. If they do this maintenance work themselves, there appears to be a strong argument that they cannot legally favor healthier neighborhoods over weaker neighborhoods, if such an allocation of municipal services clearly harms minority residents. Because cutting grass and boarding up houses are not meant to last for a long time, much less produce long-term financial returns, the feasibility arguments about the capital resources needed for rehabilitation would not apply to these nuisance mitigation steps. Without these nonracial justifications for treating poorer neighborhoods differently from more stable areas, a municipal vacant house mitigation program is more susceptible not only to a possible disparate impact claim under the Fair Housing Act but also to disparate treatment claims under any of the relevant civil rights laws. Any city government that cannot explain why it is putting more of its cleaning and boarding resources into more stable neighborhoods leaves itself open to the charge that it cares less about the concerns of minority residents than those of white citizens.

The main source of legal concern for those managing code enforcement and land-banking responses to vacant houses comes from these policies' consequences for the availability and location of affordable housing. Any reduction in affordable housing or any limiting of low-income housing opportunities to areas already having significant racialized concentrations of poverty will support a disparate claim against the policy causing the harm. The Eighth Circuit Court of Appeals decision in Gallagher v. Magner ${ }^{56}$ illustrates how a code enforcement policy, albeit one focused on occupied properties, became vulnerable to a disparate impact challenge based on negative consequences for housing affordability.

Soon after the City of St. Paul created the Department of Housing and Neighborhood Improvement in 2002, the Department began to pursue a

56. 619 F.3d 823 (8th Cir. 2010). 
proactive and exacting approach to housing code compliance focused on rental properties. Landlords complained that this strict enforcement on absentee-owned properties made the cost of property management more expensive. Two years later, various landlords filed complaints in federal court alleging, among other things, that, by subjecting rental properties to stricter enforcement, St. Paul's code enforcement officials had made housing less affordable, a consequence that disproportionately impacted the ability of minorities to find suitable housing. The city argued, with some success at the trial court level, that the landlords' theory of the case was that the Fair Housing Act protected the rights of minorities to live in substandard housing. The Eighth Circuit, however, reinstated the landlords' disparate impact claim, noting independent evidence supporting the landlords' contention that St. Paul's housing code was more demanding of landlords receiving federal subsidies than the Federal Housing Quality Standards, which also applied to their units because of the subsidies involved. ${ }^{57}$ The court also found sufficient evidence to warrant a trial on whether or not aggressive code enforcement had forced affordable units out of service to low-income tenants. ${ }^{58}$ Although the U.S. Supreme Court granted certiorari, the case was settled before argument was heard, leaving the Eighth Circuit holding in place.

The Magner court's approach to evidence showing a reduction of affordable housing as justification for a trial on fair housing disparate impact claims should be very concerning to code enforcement officials generally but not especially to those advocating market-smart approaches to vacant houses. While the landlord plaintiffs and the court noted the higher level of scrutiny applied to absentee-owned properties, the fact that enforcement of St. Paul's code may have resulted in more disqualified units than the existing federal standards would have played the critical role. Any further proceedings would have considered not only all the evidence relevant to that issue but also any justifications St. Paul would have had for having higher standards than Housing Quality Standards imposed on Section 8 and other federal subsidy recipients. Nevertheless, it would appear that public actions that lead to landlords exiting the lower tiers of the rental market may invite protracted litigation. Still, code enforcement responses to properties that have already gone out of service do not face these same issues.

As briefly described above, a market-sensitive code enforcement approach to abating vacant house nuisances deploys different remedies depending on the financial prudence of making the necessary repairs, a factor strongly influenced by the strength of the neighborhood real estate market. The order-to-repair remedy would more likely be pursued in healthier neighborhoods. Areas with greater concentrations of vacant

57. Id. at 834 .

58. Id. 
houses would see their municipal code enforcement departments pursue demolition or just accept an owner's commitment to keeping a vacant property clean and secure. The rationale behind this differentiation is to make sure that code enforcement resources are used effectively. Rather than try, in all cases, to obtain full compliance through coerced rehabilitation, some severely dilapidated houses would be written off largely because of the neighborhoods they are in.

At first blush, this triage approach to the repair-order remedy would appear to result in fewer rehabilitated properties in poorer neighborhoods than an approach that attempted to obtain full compliance no matter the economic feasibility of rehabilitation would. Even a generally futile attempt to force rehabilitation might get lucky from time to time. A strategy that prejudged and dismissed the possibility of full compliance would miss these victories, however few or fleeting they might be. Given that many of the neighborhoods with high concentrations of vacant properties also have higher proportions of low-income and African American residents, the social justice critique against using neighborhood market strength maps to shape code enforcement begins to take shape.

The starting point for a civil-rights-based attack on such a strategy, however, would be an overall loss of affordable housing opportunities, not just a loss of habitable properties in distressed neighborhoods. By concentrating full-compliance efforts in neighborhoods with stronger markets, code enforcement officials may succeed in putting more vacant properties back in productive use than they would have under a less-focused approach. Moreover, the rehabbed vacant properties in healthier neighborhoods would often be available to low- or moderate-income households for two reasons. First, even neighborhoods healthy enough to support financial return on rehabilitation investment often have low enough land values to produce modest rents or home purchase prices. Second, these renovation project margins are sometimes so small as to be feasible only with the help of a low-income housing subsidy or a federal historic tax credit, both of which promote occupancy by low- or moderate-income households. ${ }^{59}$ Moreover, these units would tend to be located in inner-city neighborhoods with somewhat lower concentrations of poverty, thereby decreasing the socioeconomic isolation of these low-income residents. Thus, a total increase of rehabbed houses, even one resulting from a strategy focusing on healthier neighborhoods, would be a net positive for the quantity of available affordable housing.

It should be noted that the case for market-sensitive code enforcement as a tool for fostering affordable housing works whether the strategy for

59. The federal Rehabilitation Investment Tax Credit requires that the renovated historic structure be held as investment property (i.e., be rented out) for at least five years after completion. Tax Incentives for Preserving Historic Properties, TeCh. Pres. Servs., http://www.nps.gov/tps/tax-incentives.htm. 
distressed neighborhoods focuses on harm mitigation through orders to keep the properties clean and secure or on nuisance abatement through demolition. The argument could be made that demolition, by eliminating the possibility of rehabilitation for the removed structure, reduces the number of potential affordable housing units, but this claim fails to account for the legal limits placed on involuntary demolitions and the prospects for new construction. In states that provide local officials with the power to tear down properties that are not in immediate danger of collapse, the law nevertheless requires that demolition be a necessary means to, if not an outright last resort for, nuisance abatement. Those properties that meet the legal requirements of involuntary demolition, by definition, have little or no prospects of being rehabilitated at any point in the foreseeable future. Hence, clearing those structures away does not eliminate even potential units of affordable housing. Moreover, in many circumstances, new units of housing can be constructed for amounts of money comparable to what full-scale rehabilitation would involve, especially when the costs of demolition and removal of debris are subtracted out. Assuming zoning restrictions do not forbid the creation of new affordable units on the existing parcels, demolition may actually increase the possibility of the property being used again as a residence.

If a Magner-type Fair Housing Act claim against a market-sensitive vacant house code enforcement strategy cannot even clearly establish a reduction in affordable housing, what kind of fair housing claims might concern officials that use neighborhood market strength maps in landbanking decisions, particularly those concerning when and how to make acquired properties available for redevelopment? Certainly, a land-bank strategy of coordinating investment in more distressed neighborhoods could have an effect on the availability of affordable housing. But a policy of refusing offers to buy individual land-bank properties in distressed neighborhoods, in order to facilitate bundled sales, would not necessarily harm affordable housing at all. Even if the turning away of single-property development offers did slow the conversion of vacant properties into affordable homes, a municipal bid process on bundles might facilitate dedication of some units to the needs of low- and moderate-income households. For instance, requests for proposals to buy bundled properties might call for at least 20 percent of the units to be developed as affordable housing. By making sure that disposition processes respond to housing affordability concerns, land banks can certainly avoid any entanglement with the requirements of the Fair Housing Act.

The more fundamental antagonism toward a land-banking redevelopment focus for distressed neighborhoods and a vigilant pursuit of full compliance with the housing code in healthier areas flow from the perceived political judgment that poor, predominantly African American neighborhoods require radical change. Long-time residents of neighborhoods beset by large numbers of vacant houses are asking their local leaders to help make their communities like they used to be. City officials that tell 
them that such a goal may be unrealistic are called out when it is clear that code enforcement resources are being used to hold the line and turn back the clock on neighborhoods where deterioration is not nearly as severe.

Ultimately, a neighborhood development strategy must look beyond the problem of vacant houses to move toward a truly just and prosperous community. Residents of distressed communities that are being readied for major investment must be involved in that redevelopment planning. Where new investment presents a threat of displacement, affordability protections such as property tax increase protections, inclusionary housing, and community land trusts should be explored. The foundation for such dialogue and partnership, however, should begin at the nuisance abatement and land-banking stages.

\section{Communicating the Fair Housing Benefits of Market-Sensitive Vacant House Strategies}

Clear policies and training of personnel are essential to avoid deliberate discrimination. A thoughtful review of the affordable housing consequences of code enforcement and land-bank policies can help ensure healthy and meaningful compliance with the Fair Housing Act and eliminate any disparate impacts of a given code enforcement policy. But effective communication is essential to safeguarding eligibility to receive federal community development and housing funds. Participating jurisdictions that receive Neighborhood Stabilization Program and Community Development Block Grant funds should be prepared to convey to HUD the benefits to housing affordability and racial integration that market-sensitive vacant property policies can bring. This same proactive approach to showing that innovative and efficient approaches to vacant property remediation actually further fair housing goals can also be used to discuss these policies with community residents directly affected by them and as a starting point to seek input from those communities. Those managing the civil rights vulnerabilities of market-sensitive vacant property strategies should always remember: The best defense is a good offense.

Whether through code enforcement or land banking, market-sensitive vacant house remediation involves reconnecting abandoned properties to a functioning real estate market. Low-income and minority residents of distressed neighborhoods may perceive any initiatives to stimulate the market as moves to foster gentrification and, with it, displacement of the poor. But by better understanding the market realities of their struggling neighborhoods, city officials can explain to both HUD and their own constituents how returning abandoned properties to productive use will bring about a more equitable as well as a more prosperous community. First, municipal housing and community development agencies must be prepared to work with the new data-driven AFH. The mapping of neighborhood market strength that market-sensitive vacant property strategies require can provide a strong understanding of the forces that also shape 
racial and socioeconomic segregation. ${ }^{60}$ With these data, vacant property strategists can show how they are stabilizing communities that continue to provide both subsidized and unsubsidized affordable units. They can also articulate how their land-banking strategies are providing opportunities for distressed areas to reemerge as mixed-income communities. By infusing affordability protections, where appropriate, into land-bank disposition policies, these revitalization efforts have the potential to foster sustainable, economically diverse communities of choice. By bringing neighborhood homeowners and tenants into these short-term and longterm planning processes, innovative community development officials can build understanding and a sense of ownership among residents. In the end, city officials should not be satisfied with showing that their market-oriented vacant property remedies do not violate civil rights laws; they must be willing to show how they further fair housing and a more just city and metropolitan area.

60. For an explanation of how data can inform vacant property strategies, see Ira Goldstein, Using the Market Value Analysis to Analyze Markets, Set Strategy and Evaluate Change, THE ReINvestMENT Fund (2013), available at http://www.trfund. $\mathrm{com} /$ using-the-market-value-analysis-to-analyze-markets-set-strategy-and-evaluatechange/. 
